\title{
水撃現象を活用した多段パルスウォータジェット発生システム*
}

\author{
山根 浩 二*1, 松 田哲*2

嘉数田隆昌*2, 河崎澄*1

\section{Multiple Water Jetting System by Means of Water Hammer}

Koji YAMANE*3, Satoru MATSUDA,

Takaaki KASUDA and Kiyoshi KAWASAKI

${ }^{* 3}$ Department of Mechanical Systems Engineering, The University of Shiga Prefecture, 2500 Hassaka, Hikone-shi, Shiga, 522-8533 Japan

\begin{abstract}
We developed a multiple pulsed water jetting system by means of water hammer in a convergent pipeline caused by strong spool acceleration. In the present study, the computer simulation of pump line-nozzle system demonstrated that an operation and the injection pressure are satisfactory as a multiple water jetting system. The triple jetting was obtained by single operation signal for the electromagnetic pilot valve system at an optimum orifice diameter in oil paths in present system. In experiments, the piercing time of work by water jet was reduced by triple jetting at the same standoff distance between nozzle outlet and work.
\end{abstract}

Key Words: Fluid Power Systems, Water Hammer, Water Jetting, Pipe Line, Pressure Wave

\section{1. まえがき}

水噴流の持つ速度エネルギーを利用するウォータ 一ジェット技術は，熱の影響を嫌う食品などの切断に 適用され急速に普及している．水噴流を加工用工具と して利用する場合，水噴流は定常噴流と非定常流に大 別される．同一噴射速度において，後者は前者よりも ターゲットに作用する衝突圧力が数倍高くなる(1).こ れは, ターゲットに衝突する際に生じる水撃作用によ るもので，水噴流の非定常化（パルス化）がウォー夕 ージェット加工に有効であることを示している．水噴 流のパルス化の方法としては定常噴流を機械的に遮断 する，ピストンの衝突や火薬の爆発力を利用する方法 听どが考案されているが，ノズル形状の複雑化やノ ズルの耐久性の問題から試験的に使用されているもの の実用化には至っていない.

これまでに著者らは，スプール油圧加速式のディ 一ゼル機関用高圧燃料噴射装置の原理を応用したパル ス式高圧ウォータージェット加工システムを開発し， 本装置が図 1 に示されているような非加熱軟質材料の

* 原稿受付 2004 年 4 月 23 日.

*1 正員, 滋賀県立大学工学部(画522-8533 彦根市八坂町 2500)

$* 2$ 学生員, 滋賀県立大学工学部.

E-mail : yamane@mech.usp.ac.jp
自在加工®に有効であることを明らかにしている。し かし, 加工時間の短縮あるいは適用材料の拡大のため には, 本装置の加工能力を向上させる必要がある.

そこで本研究では, 計算機シミュレーションのによ って系の一回の起動によって複数の圧ピークを有す る多段噴射の発生条件を調べ，さらに実機によってこ れを実現し，その有効性を実験的に明らかにした。

\section{2. パルスウォータージェット発生装置}

高圧パルスジエット発生装置の主要緒元を表 1 に, 構成図を図 2 に示す。本装置のポンプ部は自由ピスト ン方式のスプールおよびプランジャ, アキュムレータ 一, 系の起動用の電磁パイロット弁（EMPV），およ

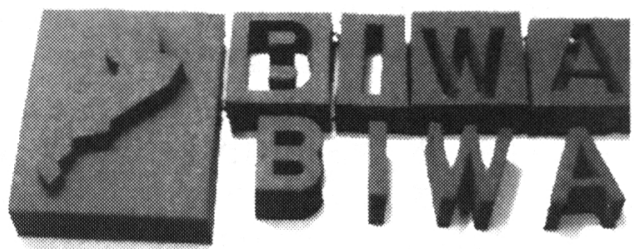

Fig.1 Stencil cutting of Lake"BIWA" from natural sponge rubber by using the present water jetting system 


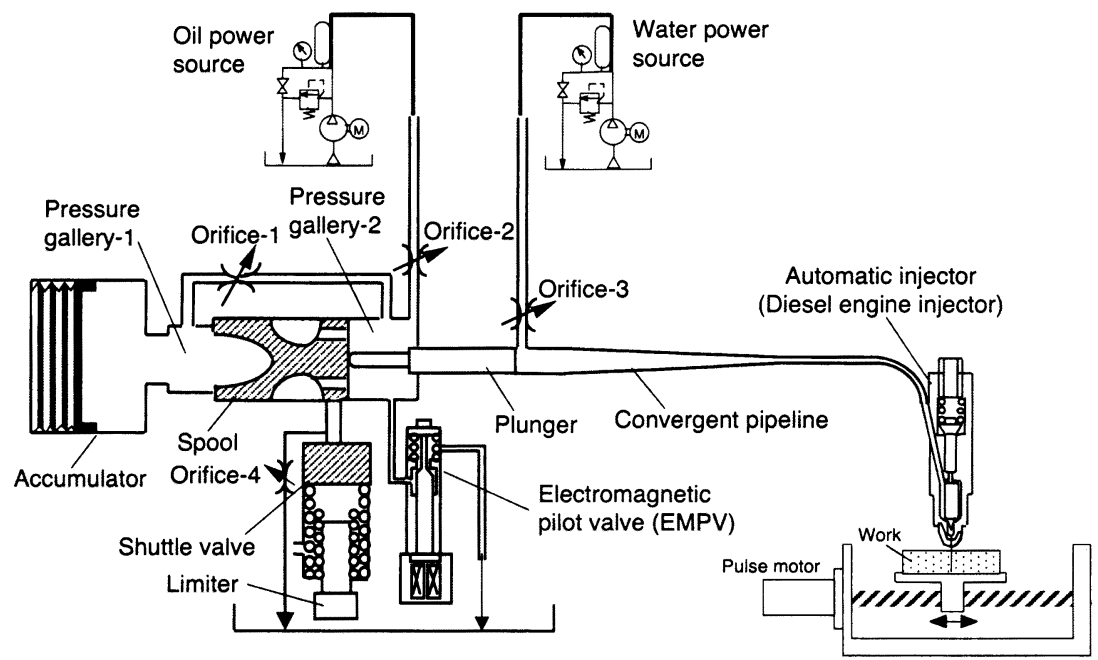

Fig.2 Schematic illustration of pulsed water jetting system

ひ噴射圧力調整用のシャトル弁から主に構成される. このポンプ部は縮小管および直管を介してディーゼル 機関用の単孔ホール型自動ニードル噴射弁に連結され ている. また，二台のパワーソースによって縮小管内 には噴射流体として水道水が，スプール前後の圧力室 には作動流体として JS2 号軽油が約 12MPa で供給さ れ，スプールおよびプランジャ（可動部）は静止状態 にある

本装置の動作方法は次のようになる．EMPV を開弁 するとスプール前後の圧力均衡が崩れ，可動部が前方 に移動し, 圧力室 2 と大気圧下のシャトル室が連通す る. 急激な作動油の流出により圧力室 2 は減圧され, アキュムレーターの蓄圧力によって可動部が急加速さ れる. プランジャ前面の縮小管入口部には水撃による 圧力波が発生し，管路内を伝播しながら増圧して噴射 弁に達すると高圧噴射が行われる。

シャトル弁が制限揚程に達すると可動部は停止し, プランジャとスプールは管路内の高圧およびオリフィ ス 2 から圧力室 2 に流入する作動油の油力を受けて逆 行を行う．スプールが着座して圧力室 2 とシャトル室 の連通孔が塞がれると, シャトル弁が復帰して初期位 置に戻る. 以上の噴射工程を数 $\mathrm{Hz} \sim 十$ 数 $\mathrm{Hz}$ の周期で 行うことで断続的にパルスジェットを噴射できる.

\section{3. 加工能力の向上の方法}

噴流の破壊力を高めるには，一般的に水に研磨材を 添加するアブレシブジェットが用いられる．高い切削
Table l Main specifications of the present system

\begin{tabular}{|c|c|c|c|}
\hline Spool & $\begin{array}{l}17 \mathrm{~mm}(\mathrm{O} . \mathrm{D} .) \\
\text { (Ceramics;SiN }{ }_{2} \text { ) }\end{array}$ & Accumulator & $\begin{array}{l}\text { 8.8 MPa(Discharge Pres.) } \\
\text { (Nitrogen charged) }\end{array}$ \\
\hline Plunger & $\begin{array}{l}6.5 \mathrm{~mm}(\mathrm{O} . \mathrm{D} .) \\
\left(\text { Ceramics; } \mathrm{SiN}_{2}\right)\end{array}$ & $\begin{array}{l}\text { Covergent- } \\
\text { Pipeline Part }\end{array}$ & $\begin{array}{l}6.5 \text { to } 1.6 \mathrm{~mm} \text { (I.D.) } \\
615 \mathrm{~mm} \text { (Length) }\end{array}$ \\
\hline Shuttle Valve & $\begin{array}{l}24 \mathrm{~mm}(O . D .) \\
\text { (Teflon) }\end{array}$ & $\begin{array}{l}\text { Straight } \\
\text { Pipeline Part }\end{array}$ & $\begin{array}{l}1.6 \mathrm{~mm} \text { (I.D.) } \\
400 \mathrm{~mm} \text { (Length) }\end{array}$ \\
\hline $\begin{array}{l}\text { Electromagnetic- } \\
\text { Pilot Valve }\end{array}$ & $\begin{array}{l}0.2 \mathrm{~mm} \text { (Max.Lift) } \\
20 \mathrm{~A} \text { (Peak Current) }\end{array}$ & $\begin{array}{l}\text { Water\&Oil Pow } \\
\text { Source }\end{array}$ & $\begin{array}{l}\text { ver } \\
12.0 \mathrm{MPa}\end{array}$ \\
\hline Injection Nozzle & $\begin{array}{l}0.26 \mathrm{~mm} \text { (Orifice Dia.) } \\
0.9 \mathrm{~mm} \text { (Orifice Length) }\end{array}$ & $\begin{array}{l}\text { Flow Control } \\
\text { Orifice Diamete }\end{array}$ & er $4 \mathrm{~mm}$ (Max.) \\
\hline
\end{tabular}

(a)

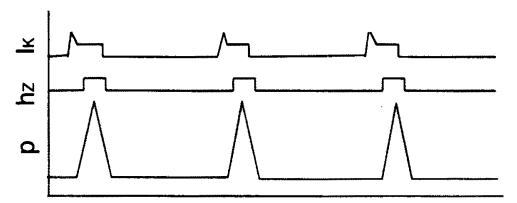

(b)

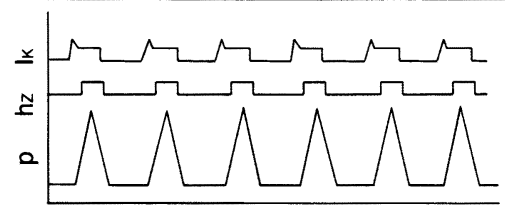

(c)

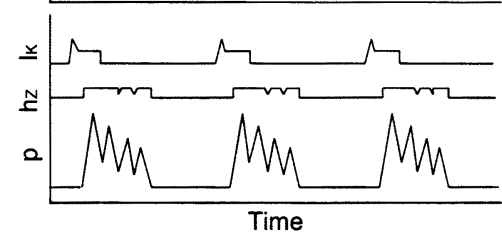

Fig.3 Improvement strategy for reduction of cutting time

力が得られるため金属など硬質材料の切断に利用され るが，添加物を併用するため使用後の固液分離の問題 や使用用途が制限されてしまう.したがって, 被加工 
物に拘わらず，清水を使用するには噴流の破壊力を高 めることが望ましい.

図 3 は本装置において考えられる加工能力の向上方 法を模式的に示した図である.ここで $p:$ 噴射圧力. $h_{Z}$ : 噴射弁二ードル揚程, $I_{K}: \mathrm{EMPV}$ の起動信号をそ れぞれ表す。本装置は(a)のように高圧パルスジェット を断続的に発生させるもので，(b)のように単位時間当 たりの噴射回数（ $f_{i}$ : 噴射周波数）を増すことで装置 の加工力を高めることができる．この方法は簡単であ るが，シャトル弁など可動部の復帰時間によって $f_{i} か ゙$ 制限される他，摺動部など系への負担が大きくなる. 一方，(c)は噴射周波数が(a)と同じであるが，噴射圧力 のピーク数 $n_{i}$ を増やしたもので，プランジャの加速に よって管路内に発生した圧力波の反射波を活用するこ とで実現できる可能性がある.この方法では被加工物 に対する噴流あるいは液滴の衝突頻度が増加するため 加工力が高く, 系への負担も増加しない. 以降, この 噴射パターンを多段噴射と呼ぶこととする.

\section{4. 計算機シミュレーションによる予測}

多段噴射は 1 噴射当たりの圧力ピーク数を増加さ せた長期間噴射である，これを実現するためには管路 内に発生させた圧力波を複数回に渡って利用する必要 がある. 通常はプランジャの素早い逆行により, 圧送 された水が吸い戻され，管路内圧力は速やかに低下す る. ここでプランジャの戻りを意図的に遅くすれば圧 力波は吸収されることなく管路内を往復するはずであ る. そこで付録に示す計算方法によって，多段噴射 の発生を予測した．計算は実機に基づく条件を用い, スプールやプランジャの動作に関係するオリフィス 1

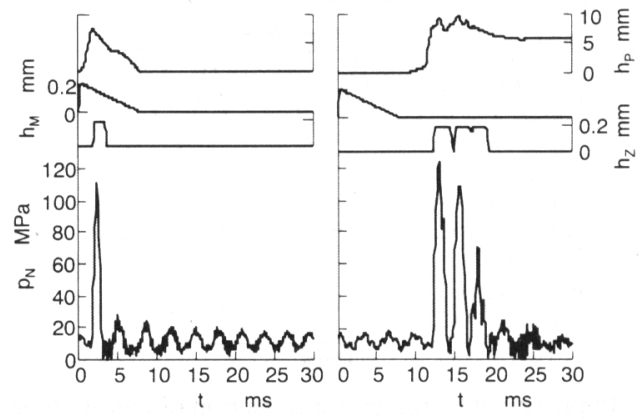
(a) $R_{o 1}=50 \%, R_{o 2}=50 \%$
(b) $R_{o 1}=10 \%, R_{o 2}=20 \%$

Fig. 4 Computed result of the courses of pressure in nozzle, $p$, nozzle needle-lift, $h_{z}$, lift of EMPV and plunger, $h_{M}, h_{P}$
および 2 の開度 $\left(R_{o}\right.$ : 通路断面積に対する開口面積の 割合）を変化させて噴射特性の変化を調査した. 図 4 に噴射弁内ギャラリ一圧力 $p_{N}$ ，噴射弁二ードル揚程 $h_{Z}$ EMPV 揚程 $h_{M}$, プランジャ揚程 $h_{P}$ の計算結果の一例 を示す。図において，オリフィス 3 の開度 $R_{033}$ は $50 \%$ 一定とした. ここで $h_{M}$ : EMPV のリフト, $h_{p}$ : プラン ジャリフトである。 また, 図 5(a)(b)には, 図 4(b)の条 件において，プランジャ出口からノズル内までの管路 内を圧力波が伝播するようすを, 各管路毎の圧力波の 時間経過および管路内の圧力プロファイルの時間経過 として表示している.

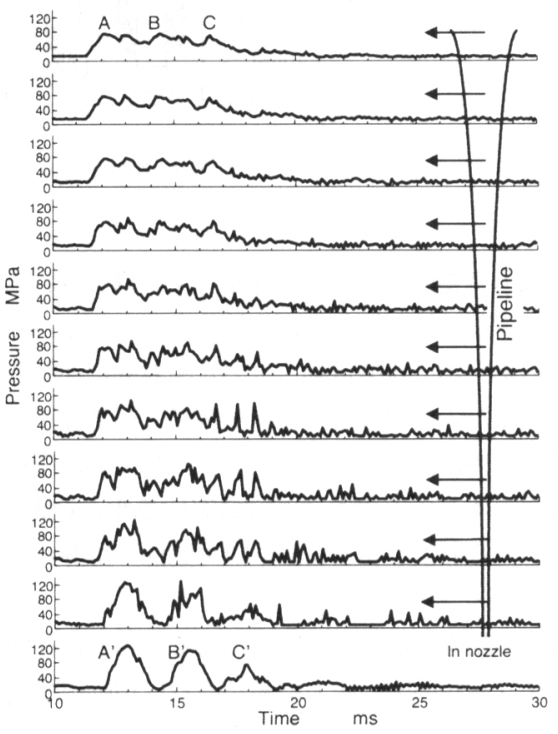

(a) Time history of pressure wave for each position

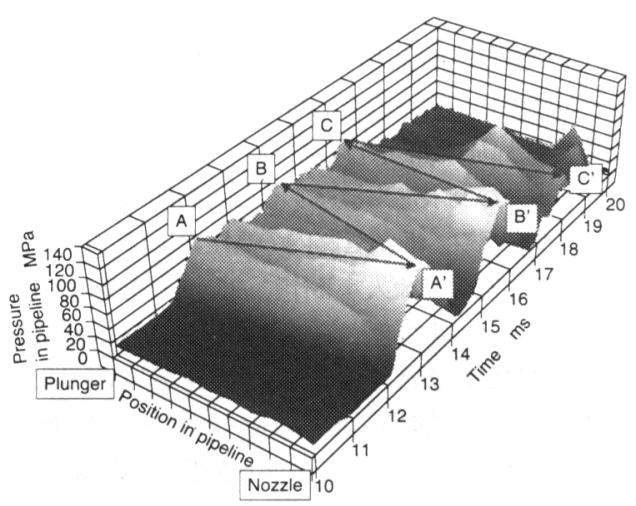

(b) Pressure wave profile in pipeline for each time

Fig.5 Computed results of pressure wave propagation in a convergent pipeline 
まず，図 4 において，(a)は通常の噴射パターンを示 しており, プランジャは速やかに初期位置へと戻って いる. ところが, (b)のようにオリフィス 1 および2を 絞ることによってプランジャの戻りが緩やかになり， 発生する圧力波の数が増加することがわかる. また, オリフィスを絞るとアキュムレーターの蓄圧力がオリ フィス 1 から逃げることなくスプールの加速に使用さ れるため圧力ピーク值も高くなる. さらに, プランジ ヤの逆行時には, 圧力室 1 から 2 へ作動油が流出でき ず流体の圧縮抵抗か強まるほか, オリフィス 2 からの 作動油の流入が制限されるため十分な復帰力が得られ ず㞍りが緩やかになる.

図 5 から, 管路内では, まず 60MPa ほどのピーク 值をもつ最初の圧力波（図(a)中の記号 A) が管路の) ズル側へ向かって伝播する間に増幅し，起動開始の時 刻 $\mathrm{t}=13 \mathrm{~ms}$ 時に約 $140 \mathrm{MPa}$ のピーク值をもつ圧力波( $\mathrm{A}$ ) となっている. その圧力波はプランジャ側へ戻り，プ

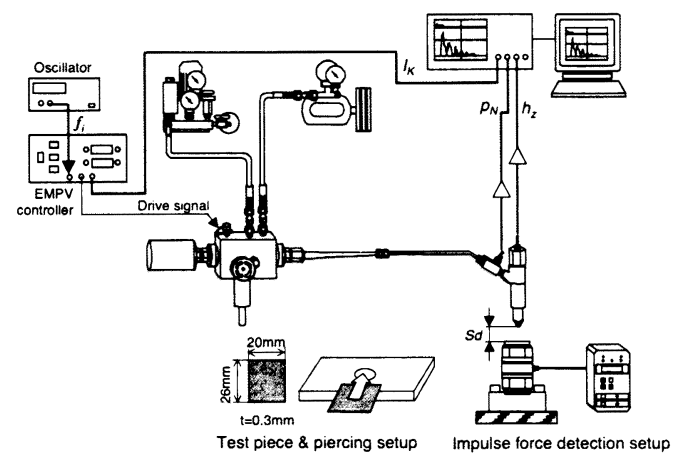

Fig.6 Schematic illustration of experimental setup
ランジャ全面で反射し圧力波(B)として再びノズル側 へ伝播し増幅して, 高い圧力波(B)となる. その後, それが再びプランジャ側へ戻った発生した反射波(C) がノズル側で圧力波(C)となっている.

以上の結果から, オリフィス 1 および 2 を絞り意図 的にプランジャの戻りを遅くすれば管路内の圧力波は プランジャの吸い戻しで吸収されることなく反射し, ノズル側で多段となって噴射されることが明らかにな った. なお，オリフィス 1 および 2 の絞りのみを種々 に変更して噴射特性を調べた結果, オリフィス 1 およ

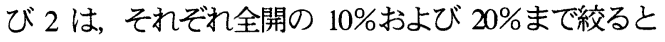
図4のような 3 段噴射が可能であることがわかった.

\section{5. 実 証 試 験}

\section{$5 \cdot 1$ 実験方法}

本研究では, 試験片の穿孔実験およひ噴流の衝撃力 計測を行い，提案する多段噴射の効果を害証した. 図 6 は実験に用いた計測装置, 試験片, 試験片固定台, 衝撃力計測系などのレイアウトを示す.

\section{$5 \cdot 1 \cdot 1$ 金属薄板の穿孔実験}

噴流の破壊力に対する多段噴射の影響を調べるため に，試験片の穿孔実験を行った。試験片は厚さ $03 \mathrm{~mm}$ のアルミニウム合金板であり，これを $\phi 5 \mathrm{~mm}$ の吹き 抜け穴を設けたテーブルに固定し, 噴射周波数 $f_{i}=$ $5 \mathrm{~Hz}$ 一定で連続噴射を行い，噴流が試験片を貫通する までの時間をストップウォッチを用いて目視計測した. 実験中はノズルホルダ入口圧力 $p_{N}$ ，噴射弁ニードル揚 程 $h_{\triangleright}$ EMPV の起動信号 $I_{K}$ を計測した. $p_{N}$ はピエゾ式 圧力変換器（AVL製 QL61D 型, 固有振動数 : $220 \mathrm{kHz}$,

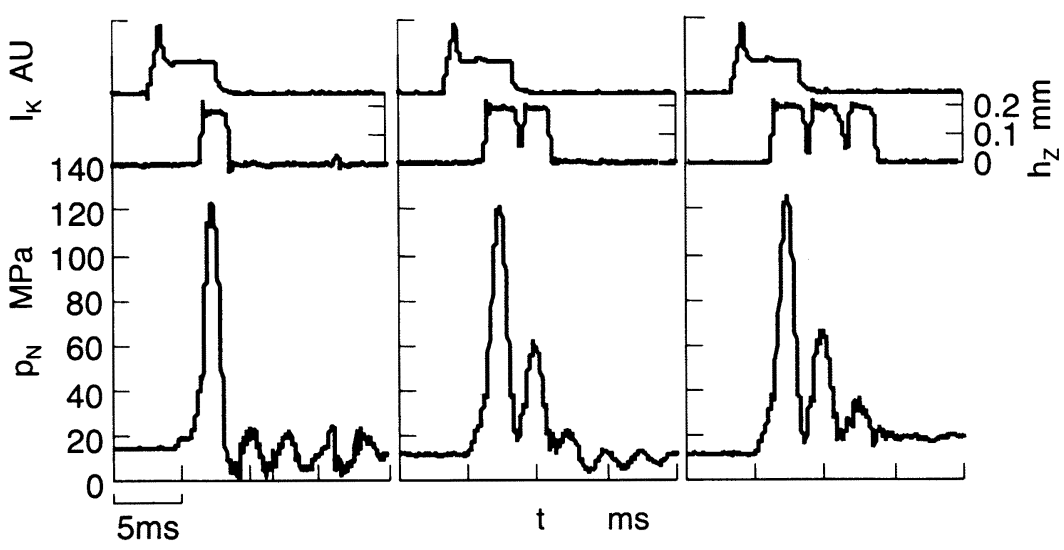
(a) Single
(b) Double
(c) Triple

Fig.7 Experimental results of the courses of pressure in nozzle inlet, $p_{N}$, nozzle needle-lift, $h_{Z}$ and input signal for EMPV $I_{K}$ at single, double and triple injections 
最大測定圧力 : $200 \mathrm{MPa}$, 直線性 : $< \pm 0.8 \%$, 感度 : $2.1 \mathrm{pC} 0.1 \mathrm{MPa})$ およびチャージアンプ（Vibromer 製 LPC630 型) により， $h_{z}$ は渦電式非接触変位計（電子応 用製 PU-05 型) を使用し，これらの信号をデジタルオ シロスコープを介してパーソナルコンピュータに取り 込み記録した. また, デジタルスチルカメラ（ニコン 製D1型）を用いて試験片の表面写真を撮影した.

$5 \cdot 1 \cdot 2$ 噴流衝撃力の動的計測

多段噴射の効果を定量的に評価するために噴流の 衝撃力の計測を行った. 計測は水晶圧電式センサ（キ スラー製 9331B) およびチャージアンプ（キスラー製 5011B10Y26）を用いて単噴流の衝突信号をデジタルオ シロスコープに取り込んだ. サンプリング周波数は $200 \mathrm{kHz}$ である.

以上の実験を 1 段, 2 段, および 3 段噴射につい て, スタンドオフ距離（Sd: 噴射弁先端から試験片表 面までの距離）を $5 \mathrm{~mm}$ から $50 \mathrm{~mm}$ まで変化させて行 った.

\section{$5 \cdot 2$ 実験結果および考察}

図 7 に穿孔実験を行った際の噴射弁入口圧力 $p_{N}$, 噴射弁二ードル揚程 $h_{Z}$ およびEMPV の起動信号 $I_{K}$ を示 す. 図の(b)および(c)では, 一度の起動信号に対して複 数回噴射されていることがわかる.これらの多段噴射 は数值計算による予測の通り, オリフィス 1 および 2 をともに絞ることで実現することができた，なお，本 実験では噴射段数の影響を比較するため, オリフィス の他にシャトル弁の制限揚程も調節してノズル入口内 圧力 $p_{N}$ の一次ピーク值を一定にした.これらの噴射 パターンによる穿孔実験の結果を図 8 に, 噴流衝撃力 の一例を図9に示す.
図 8 から噴射段数が増えるほど穿孔時間 $t_{P}$ が短縮さ れることがわかる. 特に, 噴射弁と試験片までの距離 が短い $S d=5 \mathrm{~mm}$ では, $t_{P}$ の短縮効果が著しく 3 段噴射 では 1 段噴射の 4 割程度になる. また $S d=5 \mathrm{~mm}, 10 \mathrm{~mm}$ において $t_{p}$ が大きく短縮されるので, $t_{P}$ は横這いにな り， Sdの影響を受け難くなる. つまり, 高さが変化す る凹凸形状の被加工材料に対しても，Sdに合わせて速 度を変化させる必要が無く, 一定の速さで切断加工が 行えるといった利点がある.

図 9 によれば，噴射圧力パターンに類似した噴流 衝擊力波形が計測されており，Sdの増加に伴い高周波 振動が上乗せされることが確認できる．噴射弁より噴 射された連続流は周囲空気をエントレインすることで 乱れ, 液滴・液塊となって被加工物に衝突するため, 連続流による信号に高周波振動が上乗せされる. なお， その振動幅が大きいほど局部の圧力変動が大きく被加

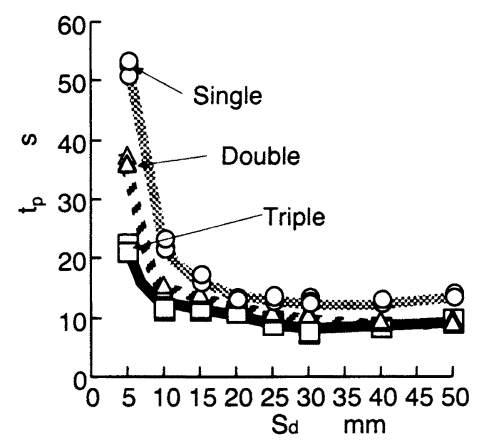

Fig.8 Effect of number of injection, $n_{i}$ in piercing period for different stand-off distance

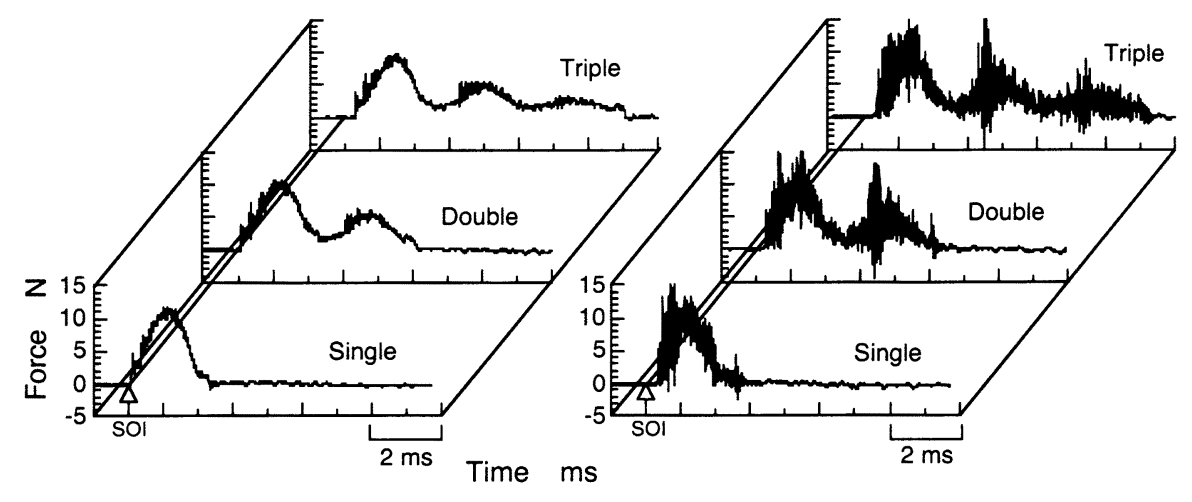

(a) $S d=5 \mathrm{~mm}$

(b) $S d=50 \mathrm{~mm}$

Fig.9 Histories of impulse force at single, double and triple jetting 


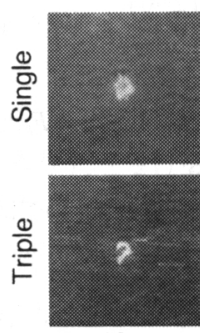

$\mathrm{t}=10 \mathrm{~s}$

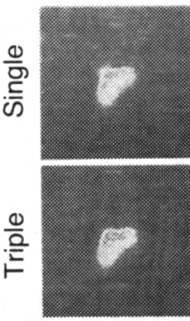

$\mathrm{t}=10 \mathrm{~s}$
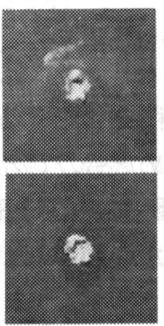

$\mathrm{t}=180 \mathrm{~s}$

(a) $\mathrm{Sd}=5 \mathrm{~mm}$
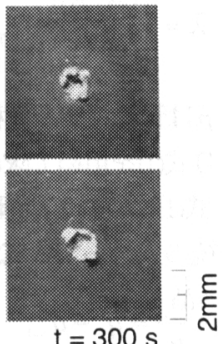

$t=300 s$

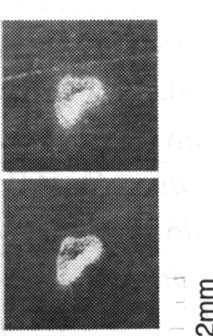

$t=30 s$

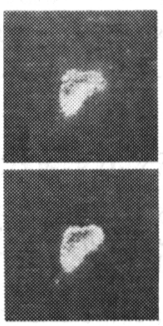

$t=20 \mathrm{~s}$
力が集中的に作用するため掘削効率が向上したと考え られ， $\mathrm{S} d=50 \mathrm{~mm}$ のように液滴・液塊としてターゲッ トに衝突する場合には，噴射量の増加に加えて噴流の 加振が起こるため微細化が促進され，液滴の衝突頻度 が高まったものと考えられる. なお， $S d=40 \mathrm{~mm}$ 以上 になると空気抵抗により多段噴射の三段目による $t_{P}$ の 短縮効果は小さくなる．また，多段噴射の作用が変化 する遷移点はおよそ $S d=20 \mathrm{~mm}$ 付近であると推察され る.

\section{6. まとめ}

本研究では，管路内の水撃現象を活用したパルスウ オータージェット発生装置の加工能力を向上させる手 段として，噴流破壊力を高める多段噴射を提案し，実 現の可能性およびその効果を確かめるために, 計算機 シミュレーションおよび実機試験を行った. これより 以下の知見を得た.

(1) 系への作動油の流入. 流出量を調整するオリフィ ス 1 および 2 を絞り, プランジャの復帰速度を意 図的に緩やかにすることによって，管路内の反射 波を複数回利用した多段噴射を実現できる.

(2) 厚さ $03 \mathrm{~mm}$ のアルミニウム合金薄板を対象に穿孔 実験を行った結果, スタンドオフ距離 $S d=5 \mathrm{~mm}$ に おいて 2 段噴射で $70 \% ， 3$ 段噴射で 40\%程度まで 穿孔時間を短縮できる.

(3) Sdは噴流構造を決定付ける重要な要素であり, Sd によって材料の破壊機構が異なる. Sdが小さい場 合では，掘削作用が優勢に働き，多段噴射によっ てこれが強調される．Sdが大きい場合には液滴の 衝撃作用が優勢となり，多段噴射によって液滴の 衝突頻度が増加する.

(4) $S d=20 \mathrm{~mm}$ では穿孔時間の短縮効果が低下する. こ れは噴流の非連続構造への遷移域にあたり, これ 以降では液滴の衝撃効果が連続流の掘削作用を上 回る.

\section{参考文献}

(1) 日本ウォータージェット学会編, ウォータージェ ツ卜技術辞典, (1993), 57-68.

(2) G. Atanov and A. Semko, Mechanics of the Powder Hydro-Cannon with the Regard of Wave Processes While Poweder Burning, Proc. of $9^{\text {th }}$ American Waterjet Conference, Vol.1, (1997), 431-440. 
(3) 山根浩二・松田哲, 高圧パルスウォータジェット による精密切抜き加工，ウォータージエット技術 年次報告会概要集, (2002-11), 17-24.

(4) 山根浩二・嶋本譲，スプールの油圧加速を利用し たパルス式高圧ウォータージェット加工システム, 噴流工学, Vol.18, No.1 (2001), 23-29.

\section{付 録}

計算機シミュレーションのための基礎方程式は，系 の各部の圧力と流量，および可動部の運動をそれぞれ 微分方程式で表現し，噴射管は慣性および容積からな る集中定数系で近似し，これを常微分方程式で記述す る. $p$ は圧力, $V$ は容積, $q$ は流量を表し, 添字により 場所を区別する. 流量は噴射管部とノズル室部に分け て考える. 各部の基礎式は以下の通りである.

a)圧力

圧力 $p$ は体積弾性率を $E$, 圧縮量を $\delta$ とすると

$$
p=E \frac{\delta+|\delta|}{2 V}
$$

このように表現すれば, $\delta<0$ の場合に圧力 $p$ は 0 に なり，液柱分離による空洞の発生を考慮できる.

ここで, 流体の密度 $\rho$ および体積弾性率 $E$ は次式の ような圧力 $p$ の一次関数とする.

$$
\rho=\rho_{0}+C_{1} p, \quad E=E_{0}+C_{2} p
$$

ただし， $C_{1}=0367 \mathrm{~kg}^{3} \mathrm{MPa}, C_{2}=9293 \mathrm{MPaMPa}$ とし， $E_{0}, \rho_{0}$ は $p=20 \mathrm{MPa}$ における值である.

b)流量

噴射管部（縮小管部）では，分割数 $n$ の慣性およ び容積からなる集中定数系で近似する. $L / n$ の長さを 持つ $i$ 番目の流体柱の運動方程式は I 番目の流量を $q_{i}$ $i-1$ 番目と $i$ 番目の管路断面積をそれぞれ $A_{i 1}$ および $A_{i}$ とすると

$$
\frac{d q_{i}}{d t}=\left(\frac{A_{i-1}+A_{i}}{2}\right) \frac{n}{\rho L}\left(p_{i-1}-p_{i}\right)-\lambda \frac{\bar{u}^{2}}{2 \bar{d}}\left(\frac{A_{i-1}+A_{i}}{2}\right)
$$

ここで, $\bar{d}, \bar{u}$ は液体柱の直径および平均流速， $\lambda$ は 管摩擦係数であり, 管路内定常流のレイノルズ数 Re に対する次式によって定める.

$$
\lambda=\left\{\begin{array}{ll}
64 / \operatorname{Re} & (\operatorname{Re} \leq 1200) \\
0.316 / \operatorname{Re}^{0.25} & (\operatorname{Re}>1200)
\end{array} \quad \ldots .\right.
$$

$p_{i}$ は管路平均断面積を $F_{L}$ とすると, $\delta$ と $V_{i}=F_{L} \cdot L n$ より式(1)を用いて求めたものである.

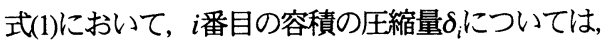
連続の式として次式が成り立つ。

$\frac{d \delta_{i}}{d t}=q_{i}-q_{i-1}$

ノズル室にはギャラリーおよびサックがあり，こ の部分の圧縮量 $\delta_{G}, \delta_{s}$ はともに噴射弁ニードルの動き と流体の出入りのみで決まる. すなわち,

$$
\begin{aligned}
& \frac{d \delta_{G}}{d t}=q_{n}-q_{S}-\left(F_{N}-F_{M}\right) \Delta h_{Z} \\
& \frac{d \delta_{S}}{d t}=q_{S}-q_{B}-F_{S} \Delta h_{Z}
\end{aligned}
$$

となる.ここでは $q_{n}$ はギャラリーへの流入流量, $h_{z}$ は 噴射弁二ードル揚程， $F_{N} ， F_{M}$ はノズル各部の断面積, $F_{S}$ は弁座面積を表す.

また, ギャラリーからサックへの流入量 $q_{s}$ およびサ ックから外部への流出量 $q_{B}$ ，すなわち噴射率は差圧が 負の場合にも考慮すると次のようになる.

$$
\begin{aligned}
q_{S} & =c_{f} F_{S S} \frac{p_{G}-p_{S}}{\sqrt{\frac{\rho}{2}\left|p_{G}-p_{S}\right|+\varepsilon}} \\
q_{B} & =c_{f} F_{0} \frac{p_{S}-p_{B}}{\sqrt{\frac{\rho}{2}\left|p_{S}-p_{B}\right|+\varepsilon}}
\end{aligned}
$$

ここで $p_{G} ， p_{S}$ は式(1)より求まるギャラリーおよびサ ックの圧力, $p_{B}$ は背圧, すなわち, 加工時の大気圧力 などである. $F_{\mathrm{SS}}$ はニードル先端部と弁座の隙間の実 効面積で, $F_{0}$ は噴孔総面積である. $C_{f}$ は流量係数であ る. また, 分母の $\varepsilon$ は正の微小数であり, これによ り圧力差が極めて小さいときに生じる計算の不安定性 を避けた. 実際の流れでは，これは層流抵抗に相当す る.

c)縮小管

従来の研究結果から, 縮小管の形状は距離 $x$ に対し て次式の指数関数形とした.

$$
A_{x}=A_{P} \exp \left(-\frac{2 b x}{L_{t}}\right)
$$

ここで, $A_{p}$ はプランジャ断面積, $b$ は定数, $L$ は縮 小管全長である.

d)スプールおよびプランジャ 
スプールおよびプランジャは一体で運動するもの として扱い, 圧力室 1 および 2 とプランジャバレル内 の圧力による力 $F_{P}$ ，スプールがシャトル室と連通し た際に生じる流体力（反力） $F_{R}$ ，および摺動面に㗢く 摩擦力 $F_{F}$ を受ける. また質量 $m$ は, スプール, プラ ンジャおよび流体の移動質量からなり，運動中は流体 の流出のため移動質量か時間変化する.

$$
\frac{d(m \dot{h})}{d t}=F_{P}-F_{R}-F_{F}
$$

ただし， $\dot{h}$ はスプールおよびプランジャの速度を 表す.

e)アキュムレーター

アキュムレーターには窒素ガスを封入した金属ベロ 一ズ式を採用し，その内部のガスの状態変化を断熱膨 張・圧縮過程として以下のように表した.

$$
\Delta V=V_{1} p_{1}{ }^{1 / \gamma} \frac{p_{2}{ }^{1 / \gamma}-p_{3}{ }^{1 / \gamma}}{\left(p_{2} p_{3}\right)^{1 / \gamma}}
$$

ただし， $\Delta V$ はアキュムレーターから圧力室 1 への 吐出量, $V_{1}$ は $p_{1}$ のアキュムレーターベローズ内のガス 体積， $p_{1}, p_{2}, p_{3}$ はそれぞれガス封入圧力, アキュム レーター最低作動圧力および最高作動圧力, $\gamma$ はガス
のポリトロープ指数であり, $p_{1}$ と $p_{2}$ との間でアキュム レーターが繰り返し作動する.

\section{f) 圧力室}

プランジャバレル, シャトル室, 圧力室 1 および 2 における圧力の算出は, 各室内の容積の圧縮量 $\delta$ から 算出する. 例えば, プランジャバレル内の圧縮量を $\delta_{p}$ とすると連続の式は

$$
\frac{d \delta_{P}}{d t}=A_{P} \dot{h}_{P}+q_{S}-q_{1}-q_{L}
$$

ただし， $q_{S}, q_{l}, q_{L}$ はそれぞれ噴射流体入りロポート からの流入量, 縮小管への流入量, プランジャ摺動面 からの漏れ量を, $A_{\rho}, \dot{h_{p}}$ はプランジャの断面積および 速度を表す。

計算は, 管路全長 $1 \mathrm{~m}$ で管路分割数を 50 とし, 以 上の多元連立常微分方程式を Runge-Kutta-Gill 法に よって $0.01 \mathrm{~ms}$ の時間刻みで数值積分して解を求めた. なお，作動流体および噴射流体である水および軽油に 用いた定数はそれぞれ次の通りである. すなわち，そ れぞれ体積弾性俰数 $E_{0} は 2100 \mathrm{MPa}$ および $1530 \mathrm{MPa}$ ， 密度 $\rho$ は $998 \mathrm{~kg} / \mathrm{m}^{3}$ および $837 \mathrm{~kg} / \mathrm{m}^{3}$, 動粘度 $v$ は $1.0 \times 10^{-6} \mathrm{~m}^{2} / \mathrm{s}$ および $4.0 \times 10^{-6} \mathrm{~m}^{2} / \mathrm{s}$ とした. オリフ イス流量係数 